\title{
CONCEPT AS A SYNTHESIS OF THE ELEMENTS OF LANGUAGE AND CULTURE
}

\author{
Popov Dmitry Vladimirovich \\ Doctor of Philosophy (PhD) in Philology,Associate Professor, Department of Russian Language and \\ Literature, Andijan State University, Uzbekistan
}

Article DOI: https://doi.org/10.36713/epra7401

DOI No: 10.36713/epra7401

\begin{abstract}
The article deals with the problem of the relationship and interaction of language and culture. Language and culture are inextricably linked, and the concept is the connecting link between them. Currently, the concept turns out to be one of the key concepts of modern linguistics, since it allows each person to enter the culture of his society and, to a certain extent, influence it. Language acts as a mechanism, without the help of which culture would not find its expression.

KEYWORDS: language of the people, culture, language and culture, concept, cultural linguistics, intercultural communication.
\end{abstract}

As we know, one of the topical issues in the field of language research at the present stage of the development of linguistics is the study of the problem of the relationship between language and culture. This issue is one of the most important, since each culture is perceived and considered in tandem with the language of the people - the bearer of the culture. At the same time, language acts as a mechanism, without the help of which culture would not find its expression. That is why it is important to know the relationship between culture and language and how they affect each other.

Language can be viewed as a surface manifestation of a person's existence in culture. Since the 19th century, with the works of J. Grimm, R. Rask, W. von Humboldt, A.A. Potebnya and to this day the problem of the relationship between language and culture is considered as a central issue in linguistics.

The first to seriously study this problem was the largest German philologist, philosopher, linguist, one of the founders of linguistics as a science W. von Humboldt [3]. The main provisions of his concept can be summarized as follows:

1) Language is the embodiment of material and spiritual culture;

2) Any culture has its own national flavor. National specificity is expressed in the language through the prism of the special worldview of each nation; the language has an internal form characteristic of each community;

3) The internal form of the language allows you to identify and reflect the "national spirit" and its cultural values;

4) Language is a mediating link between a person and the world around him [8].

The idea that the structure of language and reality is similar was reflected in the works of the outstanding Danish linguist, author of glossmatics the original structuralist theory of language - Louis Elmslev, who noted that the structure of language can be equated with the structure of reality. Or, at least, the structure of language can be perceived as a reflection of reality, albeit a little deformed, without absolute accuracy [5]. E.F. Tarasov notes that culture includes language as the "body" of a sign. It follows from this that language is a cultural subject [11]. The linguistic and communicative ability of a person is objectified in linguistic form, in the meaning of a linguistic sign, which is also a cultural formation. It arises exclusively in human activity. But culture is also included in the language. This conclusion can be reached due to the fact that the culture is completely modeled in the text [8].

However, the points of contact and interaction between language and culture need to be examined carefully. Do not forget that language and culture are different semiotic systems, which means 
that they have their own differences, as well as a lot in common, namely:

1) Such forms of consciousness as culture and language are a reflection of a person's vision of the world;

2) Culture and language exist in a dialogue with each other;

3) The subject of culture and language is always an individual or a society, a person or a society;

4) There is one common feature for language and culture - normativity;

5) Historicism is one of the essential properties of culture and language;

6) "dynamics-statics" is the antonymy that is inherent in language and culture.

Language and culture have common ground in the following:

1) In communication processes;

2) In ontogenesis;

3) In phylogeny.

Differentials between language and culture lie in the following factors:

1) Culture values elitism, selectivity, while in the phenomenon of language, preference is given to the mass addressee;

2) Culture is not capable of selforganization, although, like language, it is a sign system [8].

From the above provisions, it follows that the similarity between language and culture is not absolute. These two entities have only a similar structure.

The relationship between language and culture is an extremely complex and multifaceted picture. Today, there are several approaches to solving this issue. The first approach mainly includes the concepts of domestic scientists, among which S.A. Atanovsky, G.A. Brutyan, E.I. Kukushkina, E.S. Markarian. The main postulate of this approach is the idea that the relationship between language and culture implies movement along one vector, in one direction. It follows from this statement that culture is an integral component of reality that a person constantly encounters, and language is a direct reflection of this reality, from which it follows that language is a simple reflection of culture.

Thus, based on the postulates of the first approach, the influence of culture on the language becomes obvious. However, the question of the reverse impact of language on culture remains open so far. It is this question that constitutes the essence of the second approach to the problem of the relationship between language and culture. Such scientists of the 19th century as W. Humboldt and A.A. Potebnya, they considered language to be a spiritual force. They believed that language is such an environment around us, outside of which and without whose participation we cannot live. W. Humboldt wrote that language is a kind of world that lies between the external and internal world of a person [3]. Thus, being our environment, language does not exist outside of us as an objective given. He is in ourselves, in our consciousness, in our memory. Each movement of thought changes the outline of the language. Language also changes with each new socio-cultural role. Within the framework of this approach, the school of E. Sapir and B. Whorf and various schools of the Neo-Humboldtians worked. They developed the so-called hypothesis of linguistic relativity. The main postulate of this hypothesis is the belief that people see the world differently - each through the prism of his native language [9; 17]. Supporters of this hypothesis believe that the real world exists insofar as it is reflected in language. But if each language reflects reality in a way inherent only to it, then, consequently, languages differ in their "linguistic pictures of the world." The SapirWhorf hypothesis has the following basic provisions:

1. The way of thinking of the people speaking it depends on the language.

2. The way of knowing the real world is directly dependent on the languages in which the subjects cognizing this world think [8].

In the studies of some authors, the hypothesis of linguistic relativity has received a modern, topical sound. First of all, in the works of D. Alford, J. Carroll, D. Hymes and other researchers, where the Sapir-Whorf concept was further developed. So, D. Hymes added one more principle, which consists in the idea of the existence of functional relativity of languages. According to this principle, the difference between the languages of the world lies in the nature of their communicative functions [17]. It should be noted, however, that not all scientists share the ideas of the hypothesis of linguistic relativity. There are a number of works that question and sharply criticize the position of this hypothesis. So, B.A. Serebrennikov explains his negative attitude to this hypothesis with the following arguments:

1) Objects and phenomena of the surrounding world are the source of the emergence and existence of concepts. Any language in its genesis is the result of the reflection of the surrounding world by a person, and not by a selfsufficient force, a substance that creates the world;

2) The language is highly adapted to the peculiarities of the physiological organization of a person. However, it should be remembered that these features arose as a result of long-term adaptation of a living organism to the surrounding world;

3) during the period of the primary nomination, an unequal division of the extralinguistic continuum occurs, which is explained by the unevenness of associations and differences in 
linguistic material that have survived from the time of previous eras [10].

D. Dodts, G.V. Kolshansky, R.M. White, R.M. Frumkina, E. Hollenstein. Thus, we can come to the conclusion that the hypothesis of linguistic relativity has an ambiguous attitude towards it on the part of modern linguistic scientists. Nevertheless, all researchers who are seriously dealing with the problem of the relationship between language and culture, language and thinking turn to it. This is due to the fact that it is with the help of this hypothesis that those facts of the language that are difficult to explain in any other way can be understood. An example is the ethnolinguistic works of the school of N.I. Tolstoy $[13 ; 14 ; 15]$, the linguo-anthropological works of the school of E. Bartminsky [2] and others.

Further reasoning about the relationship between language and culture refers to the third approach, the main idea of which boils down to the fact that language is a fact of culture. This hypothesis is explained by the following provisions:

1) Language makes up a significant part of the culture that we inherit from our ancestors, predecessors;

2) Language is the very main tool with which we assimilate culture;

3) Language is the most important cultural phenomenon. If we want to understand the essence of culture - science, religion, literature, then we must consider these phenomena as codes that are formed in the same way as language is formed. This is due to the fact that natural language as a classical semiotic system has the best of the existing developed models. Therefore, conceptual comprehension of culture can occur only through the medium of natural language.

As K. Levi-Stross noted, language is both a product of culture and at the same time its important component [7]. In other words, language contains the most important condition for the existence of culture. Moreover, language is a specific way of cultural existence, which is a necessary factor in the formation of cultural codes.

The relationship between language and culture can be seen as a relationship between part and whole. Language can be perceived as a component of culture and as an instrument of culture. However, language is an autonomous structure in relation to culture as a whole. It can be viewed as an independent semiotic system. According to this concept, every native speaker is also a bearer of culture. This means that linguistic signs acquire the ability to perform the function of cultural signs. Thus, linguistic signs are a means of representing the main cultural attitudes. That is why the language has the ability to reflect the cultural and national mentality of its speakers. You can relate culture to language through the concept of space. So, each culture has its own key, key words. For example, for Germans it means order, accuracy, punctuality, for Americans practicality, pragmatism, individualism, for Russians these words are soul, longing, collectivism, and for Tajiks - hospitality and cordiality. So how is the system of cultural values reflected in the language? To be a key word of culture, the word must be common, frequent, must be part of phraseological phrases, proverbs and sayings. In other words, in order to recognize this or that word as a concept (the key word of culture), it is necessary for the word to become common, frequent. In addition, a necessary condition for the recognition of a word as a concept is its entry into the phraseological and paremiological, proverbial and verbal fund of the language. Linguistic norms can be correlated with cultural attitudes. It is worth noting, however, that they are not as binding as the norms of the language. Bearers of culture, distributed in different societies, have the right to a wider choice.

So, culture lives and develops in a "linguistic shell". If earlier primitive cultures were "material", material, then modern ones are becoming more and more verbalized. Language serves culture, but does not define it. Language is capable of creating verbal illusions (in other words, stereotypes) that replace reality. The creation of social stereotypes becomes possible thanks to verbal illusions (from Lat. Verbalis - oral, verbal). An example is the existence of such national stereotypes as "German", "Chukchi", "persons of Caucasian nationality", which form national prejudices based on conversations around a person, the sound of speech. As a result, verbal cliches are being introduced into the minds of people that paint the world in the "desired color": a bright future, great indestructible friendship of peoples, great achievements, etc. It is thanks to language that a person perceives fiction as reality, experiences and comprehends what does not exist in reality, suffers and enjoys, experiences catharsis (the process and result of a purifying, facilitating and ennobling effect). All this is possible only thanks to natural language, as well as other semiotic systems (the language of cinema, the language of forms, colors, sign language, i.e. kinesics, etc.). The leading place among all these languages as sign systems is occupied by natural language, since a linguistic sign can become an indicator of culture.

Observations show that it is rather difficult to determine to the end what language and culture are, in what relations they are with each other and how great their role is in the life of a person and society. We have only tried to indicate how important it is to understand the relationship between language and culture at the present stage.

Thus, it becomes obvious that language and culture are inextricably linked, and the concept is the connecting link between them. In this regard, the concepts should be considered in the context of such 
areas as intercultural communication, teaching foreign languages, translation, international politics, diplomacy, since knowledge of the cultural characteristics of certain concepts reflected in the language will avoid misunderstandings and conflicts, which, in in turn, will improve the quality of communication between ethnic groups. After all, language is one of the most powerful social tools that unites people into an ethnos. Through the storage and transmission of culture, social identity and traditions of a particular speech community, the language forms a nation. The fact is that, even if they speak the same language, people cannot always correctly understand each other, and the reason for this is often precisely the divergence of cultures $[1 ; 6]$.

In the context of the contrast of cultures, the success and effectiveness of intercultural communication depends on a number of factors of general, global action and on the actual content of communicative acts. The first (factors of global action) determines the motivational and factual moments. Such factors include a predisposition to communication or its absence, determination of the goals of communication, its strategy and tactical behavior during communication, entry into communication, etc. The second (the content of communicative acts) implies the fact that the communicants belong to different linguocultural communities. This factor affects both the social aspects of intercultural communication and the interpersonal communication of representatives of different ethnic groups and cultures. It is worth paying attention to the fact that it is unacceptable to believe that the above factor exists in the minds of only unenlightened "naive communicants". Extensive communicative experience and educational work in the field of intercultural communication lead only to the erasure of interlanguage and intercultural boundaries and the understanding that people belonging to another ethnic group, others, to the recognition of the right to exist for others, but not to the disappearance of the very differences of linguistic cultures.

Recently all over the world there has been an increased interest in cultural problems, in the study of cultures of different peoples, and especially cultural conflicts. However, behind this explosion of interest in the cultures of other peoples, according to S.G. Ter-Minasova, there are not creative and noble goals and interests in the cultures of the world, not the desire to expand the horizons of one's own culture by enriching the experience, originality and originality of other cultures, but completely different reasons. As a result of the economic, political and social changes and upheavals that have taken place on a global scale in recent years, an unprecedented shift has occurred, which has entailed large-scale migration of peoples, and with this inevitable clashes with the indigenous population, which, of course, leads to a conflict of cultures [12].

The conflicts that arose in connection with the misunderstanding, and therefore the rejection of a foreign culture, forced to pay the closest attention of the public and science to the problems of intercultural communication. True, the issues of intercultural communication are eternal, they have worried human society from time immemorial. So, in Ancient Greece and Rome, all foreigners and representatives of other cultures were called barbarians (from the gr. Barbaros). This word has an onomatopoeic nature, and it is associated with a foreign language; nonnative languages were perceived by ear as an indistinct bar-bar-bar. This issue was also reflected in the proverb, which is in many languages of the world: В чужсй монастырь со своим уставом не ходят (Russian); When in Rome, do as Romans do (English). Thus, we can conclude that folk wisdom in each of these languages is trying to warn its people and thereby protect them from a possible conflict of cultures. Native culture here acts as a kind of shield that protects the national identity of the people, its originality. At the same time, it acts as a blank fence that separates the native culture from other, perceived as alien, cultures. Thus, the whole world is divided into two opposite poles: "ours" / "aliens", where "ours" are united by language and culture, which "aliens" do not know. Such an axiological value differentiation of "one's own" / "someone else's" is at the heart of human life. This explains the fact that in intercultural communication, we, first of all, inevitably encounter prejudices, presuppositions and evaluative stereotypes, which significantly affect the process of communication from its beginning to the end. The main factor for intercultural communication is the cultural, or otherwise, linguistic (semiotic) border. From the very beginning, this implies the existence of a "friend" / "alien" model of communication, which the communicants define for themselves and the interlocutor. The model of communication "ours" and "aliens" is not meant by the communicants as simply a change of roles in the dialogue. This communication model marks speech (language, culture) as something that is "beyond the border" of its culture and language. It does not take into account that the speech is conducted in one of the languages of the communicants themselves, or in an intermediary language, or with the assistance of an interpreter. In any of these cases, the communicants are faced with a foreign culture and mentality. Such a practice in communication with the use of the label "friend" / "foe" does not imply obligatory confrontation and aggressive confrontation. Very often, communicators are looking for common ground in the language and culture of their interlocutor in order to increase the effectiveness of mutual understanding and thereby achieve the most 
successful communication. To this end, the communicants are trying to bring together the elements of the worldview predetermined by linguistic culture. Thus, we can come to the conclusion that in intercultural communication, a certain constant is the mutual recognition of the presence of a semiotic border.

The most vivid and obvious examples of unsuccessful intercultural communication and cultural clashes are the everyday communication of foreigners. Such conflicts become, at best, a source of anecdotes and curiosities, at worst - the cause of troubles and tragedies.

The problems of intercultural communication affect all spheres of human life in contact with other cultures. In particular, one-sided: when getting acquainted with foreign fiction, art, cinema and theater, radio and television, when reading foreign press, as well as in connection with the use of the most popular and widespread communication system in our time - the Internet. Unilateral contact with a foreign culture and the conflicts arising in connection with this are called indirect, indirect, in contrast to the direct conflict of cultures that occurs during real communication with representatives of other ethnic groups. With unilateral contact, the cultural barrier is practically invisible and unconscious, which, however, makes it even more dangerous. For example, when getting acquainted with foreign literature, the reader inevitably comes across a foreign culture, the culture of another, unfamiliar country and enters into conflict with it. Reading by foreign authors is, figuratively speaking, an act of invasion "into a foreign monastery." In the process of acquaintance with foreign literature, the reader inevitably evaluates a foreign culture and the world through the prism of his own worldview and worldview formed by the culture of his country, which entails a deeper awareness of the reader of his own culture, his world outlook and attitude to life and to people.

Summarizing all of the above, it becomes obvious that such a difficult situation poses the following tasks for science:

1. to conduct a thorough study of the roots, manifestations, forms, types, development and differences of cultures of different peoples, as well as their contacts;

2. to instill in people a sense of tolerance towards other cultures and ethnic groups.

To accomplish the above tasks, linguistics, along with other sciences, began to study concepts as a reflection of the worldview and worldview of various ethnic groups.

In the online encyclopedia "Krugosvet" the following explanation of the term "tolerance" is given: "Tolerance (tolerance) is the desire and ability to establish and maintain community with people who differ in some respects from the prevailing type or do not adhere to generally accepted opinions" [18]

According to the Declaration of Principles of Tolerance, adopted by the General Conference of UNESCO (1995), “Tolerance means respect, acceptance and correct understanding of the rich diversity of cultures in our world, our forms of selfexpression and ways of manifesting human individuality. It is harmony in diversity, it is a virtue that makes it possible to achieve peace and contributes to the replacement of the culture of war with a culture of peace ..." [4].

Tolerance is extremely important in the modern world, in an age of globalization and everincreasing mobility, integration and interdependence, the rapid development of communication and interpenetration of cultures, in an age of large-scale migrations and a radical transformation of social structures. Human society is based on differences between people, due to which the escalation of intolerance and interethnic conflicts potentially threatens the whole world, and it is impossible to isolate oneself from such a threat by national borders.

An exceptionally close connection and interdependence is observed today between the teaching of foreign languages (including Russian as a non-native one) and intercultural communication, in connection with which the awareness and solution of issues of intercultural communication in modern linguodidactics is of particular importance. At each lesson, educational lesson in a foreign language, there is a contact and intersection of cultures, since every word in a foreign language is a mirror image of a foreign (alien) world and foreign culture. Every word conceals an idea of a different world, conditioned by the national consciousness of another ethnos.

The close connection and interdependence of languages and cultures and the obvious need for their co-study does not raise any doubts today. However, here it is necessary to make an important methodological remark: the essential features and differences of languages and, accordingly, cultures are manifested in a comparative analysis, in a comparative study of languages (respectively, and cultures). Integral and differential features of languages, as well as the cultural barrier, are not visible at the level of only one culture and language. The linguistic and cultural barrier becomes obvious, obvious only when the native culture collides with someone else's mentality and worldview of a different order, which differ from their own worldview. At best, these differences are perceived as surprising, but more often they are just strange, unpleasant and shocking.

This is where the concept of culture shock comes from. Enclosed in the framework of their own 
culture, people are entrenched in the strong illusion of their own special vision of the world, mentality and way of life. This world and way of life are perceived as the only possible and the only acceptable.

However, the problem is that most people do not recognize themselves as a product of their culture, even if they understand that the behavior of representatives of other ethnic groups is determined by their other culture. This means that no one considers it necessary to change anything in their consciousness. The problem of intercultural communication can be solved only by going beyond the framework of your culture. In other words, only when faced with a different worldview, attitude, etc. you can understand the specifics of your social consciousness and see with your own eyes the difference or conflict of cultures.

Thus, it becomes quite clear that the cultural barrier is much more unpleasant and dangerous than the linguistic one, and it is not felt until a person encounters this barrier, invisible until a certain moment. The danger of intercultural communication also lies in the fact that language mistakes are not perceived as painfully as cultural mistakes, despite the fact that people are more lenient about a person's ignorance of a foreign culture, since cultural differences are not generalized into sets of rules: cultural issues are not issued dictionaries as in the language. Language mistakes of foreigners related to interference, accent, etc., as a rule, are met by native speakers with a smile, while cultural mistakes often produce a much more unpleasant impression.

The human essence lies in the understanding only of what is already known and understood, rather than the knowledge of the new. After all, communication systems, including language, to a certain extent were created out of fear of the unknown undividedness of the surrounding world. And the known, designated and dismembered world is reproduced in daily discourses as its own nonaggressive and comfortable world.

\section{REFERENCES}

1. Vereshhagin E.M., Kostomarov V.G. Jazyk $i$ kul'tura: Lingvostranovedenie $v$ prepodavanii russkogo jazyka kak inostrannogo. - Moskva: Russkij jazyk, 1983. - 246 s.

2. Bartminskij E. Jetnocentrizm stereotipa: rezul'taty issledovanija nemeckih (Bohum) $i$ pol'skih (Ljublin) studentov v 1993-1994 gg. // Rechevye $i$ mental'nye stereotipy $v$ sinhronii $i$ diahronii. - Moskva, 1995. - S. 7-9.

3. Gumbol'dt fon V. Jazyk i filosofija kul'tury. Moskva: Progress, 1985. - 448 s.

4. Deklaracija principov terpimosti: Utverzhdena rezoljuciej General'noj konferencii JuNESKO ot 16 nojabrya $1995 \mathrm{~g}$. [Jelektronnyj resurs]. Rezhim dostupa: URL: http://tolerance.ru/tolerdeklaraciya.php (data dostupa: 16.06.2021).
5. El'mslev L. Prolegomeny k teorii jazyka / Per. s angl. / Sost. V.D. Mazo. - Moskva: URSS, 2006. $248 s$.

6. Karasik V.I. Jazykovoj krug: lichnost', koncepty, diskurs. - Volgograd: Peremena, 2002. - 477 s.

7. Levi-Stross K. Strukturnaja antropologija. Moskva: Izdatel'stvo Jeksmo-Press, 2001. - 512 $s$.

8. Maslova V.A. Lingvokul'turologija. - Moskva: Akademija, 2001. - 208 s.

9. Sepir Je. Izbrannye trudy po jazykoznaniju $i$ kul'turologii. - Moskva: Progress, 1993. - 655 s.

10. Serebrennikov B.A. O materialisticheskom podhode k javlenijam jazyka. - Moskva: Nauka, 1983. - 319 s.

11. Tarasov E.R. Jazyk i kul'tura: Metodologicheskie problemy // Jazyk - Kul'tura - Jetnos. - Moskva: Nauka, 1994. - S. 105-112.

12. Ter-Minasova S.G. Jazyk $i$ mezhkul'turnaja kommunikacija. - Moskva: Izdatel'stvo Moskovskogo gosudarstvennogo universiteta, 2004. - 352 s.

13. Tolstoj N.I. Jazyk i narodnaja kul'tura: Ocherki po slavjanskoj mifologii $i$ jetnolingvistike. Moskva: Indrik, 1995. - 262 s.

14. Tolstoj N.I., Tolstaja S.M. O zadachah jetnolingvisticheskogo izuchenija Poles'ja // Polesskij jetnolingvisticheskij sbornik. - Moskva, 1983. - C. 3-21.

15. Tolstoj N.I. Jetnolingvistika v krugu gumanitarnyh disciplin // Russkaja slovesnost'. Ot teorii slovesnosti $k$ strukture teksta. Antologija. Moskva: Academia, 1997. - S. 306-315.

16. Uorf B.L. Otnoshenie norm povedenija $i$ myshlenija $k$ jazyku // Novoe $v$ zarubezhnoj lingvistike. - Moskva, 1960. - Vypusk 1. - S. 135168.

17. Hajms D.H. Dva tipa lingvisticheskoj otnositel'nosti // Novoe v zarubezhnoj lingvistike. - Moskva: Progress, 1975. - Vypusk VII. - S. 229-298.

18. Jenciklopedija «Krugostvet» [Jelektronnyj resurs]. - Rezhim dostupa: URL: https://www.krugosvet.ru/enc/gumanitarnye_nauk i/filosofiya/TOLERANTNOST.html (data dostupa: 10.06.2021). 